\title{
Changing pattern of clinical illness in children with group A streptococcal bacteremia
}

\author{
KIM J BURROWS, MD, SCOT A HALPERIN, MD, MARGARET SWIF, ART, ROBERT BORTOLUSSI, MD
}

KJ BURRows, SA HALPERIN, M SWIFT, R BORTolussi. Changing pattern of clinical illness in children with group A streptococcal bacteremia. Can J Infect Dis 1993;4(6):341-346.

OBJEcTIVE: To test the hypothesis that bacteremia caused by group A streptococci (GAS) has become more common and the presentation of the infection more severe in the Izaak Walton Killam Hospital for Children during the past decade. Design: Retrospective analysis by laboratory log and chart review. Serting: A pediatric teaching hospital providing primary and tertiary care. REsults: There was no difference in the frequency of detection of GAS bacteremia between the two periods studied (1980 to 1988 and 1988 to 1991 ). However, severe GAS infection with deep tissue invasion was more common in the last three-year period (77\% versus $11 \%, \mathrm{P}=0.01)$. Severity, as measured by length of hospital stay, was also greater in the recent group ( 17.9 days versus 3.3 days, $\mathrm{P}=0.03$ ). A recent group of four children was identified with a unique clinical syndrome of rash, severe myalgias, hyperesthesia, and refusal to bear weight. ConcLusion: The number of cases of severe GAS disease has increased in the past several years, and GAS infection should be included in the differential diagnosis of seriously ill children. GAS infection must be managed aggressively with vigilance for additional deep tissue involvement, even while on appropriate antimicrobial therapy.

Key Words: Group A streptococci, Invasive group A streptococcal disease, Severe streptococcal infection; Streptococcal bacteremia, Toxic shock-like syndrome

\section{Modification de la maladie clinique chez les enfants atteints de bactériémie streptocoques du groupe A}

OBJEcTIF: Vérifier l'hypothèse selon laquelle la bactériémie causée par des streptocoques du groupe A soit devenue commune et que sa présentation se soit aggravée, à l'hôpital pour enfants Izaak Walton Killam, au cours de la décennie écoulée. Modèle: Analyse rétrospective d'archives de laboratoire et revue des dossiers. Contexte: Centre hospitalier universitaire pédiatrique qui dispense des soins primaires et tertiaires. Résultats: Aucune différence n'a été notée au plan de la fréquence de détection des bactériémies à streptocoques du groupe A entre les deux périodes étudiées (1980 à 1988 et 1988 à 1991). Cependant, l'infection grave à streptocoques du groupe $\mathrm{A}$, avec atteinte tissulaire profonde, a été plus fréquente durant la dernière période de trois ans $(77 \%$, contre $11 \%, \mathrm{P}=0,01)$. La gravité mesurée par la durée du séjour hospitalier s'est également révélée plus importante dans le groupe le plus récent (17,9 jours contre 3,3 jours, $\mathrm{P}=0,03$ ). Un groupe rêcent de quatre enfants a été identifié avec un syndrome clinique unique de rash, de myalgies graves, d'hyperesthésie et d'incapacité de se porter. Conclusion: Le nombre de cas de maladies à streptocoques du groupe A sévères a augmentê au cours des dernières années et cette infection devrait être incluse dans le diagnostic différentiel des enfants gravement malades. L'infection à streptocoques du groupe A doit être traitée énergiquement avec surveillance prépondérante de l'atteinte additionnelle profonde des tissus, même si un traitement antimicrobien approprié est amorcé.

Department of Pediatrics and Microbiology, Dalhousie University; and the Izaak Walton Killam Hospital for Children, Halifax, Nova Scotia

Correspondence and reprints: Dr Scott A Halperin, Izaak Walton Killam Hospital for Children, 5850 University Avenue, Halifax, Nova Scotia B3J 3G9. Telephone (902) 428-8498, Fax (902) 492-0997

Received for publication November 5, 1992. Accepted April 6, 1993 
$\mathrm{I}$ N THE PAST DECADE, THERE HAS BEEN AN APPARENT RESURgence of severe group A streptococcal (GAS) disease. Outbreaks of rheumatic fever have been reported from several locations in the United States (1-7), and pyogenic GAS infections have been reported in the elderly, intravenous drug abusers and otherwise healthy adults (8-12). In adults, bacteremia, invasive disease and a toxic shock-like illness have been described (13-17). Recently, there have been reports of severe GAS disease in children including toxic shocklike illness (18-22).

Since 1989, an apparent increase in the incidence and severity of pyogenic complications of GAS infection has been noted at the Izaak Walton Killam Hospital for Children (IWK). Several cases manifested a unique clinical syndrome including a characteristic rash, myalgias and hyperesthesia. Therefore, we conducted a retrospective analysis of GAS bacteremia at this institution and compared the cases from 198991 with cases from the previous eight years to determine whether GAS bacteremia had become more common or its clinical presentation more severe. We found that although the incidence of GAS bacteremia remained the same, the severity of infection increased.

\section{METHODS}

Study design: IWK is a 211-bed pediatric teaching hospital in Halifax, Nova Scotia. It serves Canada's three maritime provinces (population 1.7 million). All cases of GAS bacteremia from March 1, 1980 to February 28, 1991 were identified from a log of all positive blood cultures at the institution during the 11-year study period. Details of the clinical course were extracted from the medical records by one investigator. The three-year period from March 1, 1988 to February 28, 1991 was compared with the previous eight years. Laboratory methods: GAS were isolated from cultures of blood by standard methods (23). Organisms suspected to be streptococci were first identified by bacitracin disc sensitivity, and group identification was achieved by slide agglutination using the Streptex Kit (Wellcome Diagnostics). Selected GAS isolates were sent to the Streptococcal Typing Laboratory of the World Health Organization Collaborating Center for Reference and Research on Streptococci at the University of Minnesota for analysis for $\mathrm{M}$ and $\mathrm{T}$ antigens and serum opacity factor. Unfortunately, earlier strains were not preserved and therefore could not be typed for comparison with the recent isolates.

Statistical analysis: Differences in proportions were compared by Fisher's exact test and differences in means were assessed by Student's $t$ test. All calculations were performed with a computerized statistics package (Statistix, Analytical Software, Minnesota) on a personal computer; $\mathrm{P} \leq 0.05$ was considered to be statistically significant.

\section{RESULTS}

There were 3027 bacterial isolates from blood at the IWK during the 11-year study period; 18 (0.59\%) were GAS.

Cases of GAS disease were not evenly distributed, with zero to four cases diagnosed per year. No cases were identified in 1987. GAS accounted for nine of 2086 bacteremias (67,637 hospital admissions) from March 1, 1980 to February 29, 1988 and nine of 1005 (23,960 hospital admissions) from March 1, 1988 to February $28,1991(\mathrm{P}=0.18)$. Ages ranged from five weeks to 15.5 years (median 5.2 years); four children were under one year of age. Two-thirds of the cases were male. All children were from the maritime provinces: three from New Brunswick, two from Prince Edward Island and 13 from Nova Scotia. There was no apparent clustering of cases.

GAS were recovered from a throat swab in 10 of 12 (83\%) patients from whom a throat culture was obtained. Most (13 of 18) children with GAS bacteremia were previously normal. One child (case 16) had unrecognized aortic stenosis and insufficiency. GAS disease was community-acquired in this child and all of the previously healthy children. Four of $18(22 \%)$ had a previously recognized underlying illness and were already hospitalized when they acquired the GAS infection (cases 2,5,9,10; Table 1).

A deep tissue infection in addition to bacteremia was more common among children diagnosed from 1988 to 1991 compared with the previous eight-year period. However, there was no difference in the frequency of children with underlying illnesses $(\mathrm{P}=0.3)$. Deep tissue infection including osteomyelitis, septic arthritis, endocarditis and meningitis developed in seven of nine $(77 \%)$ cases from 1988 to 1991 compared with only one of nine $(11 \%)$ cases in the earlier group $(\mathrm{P}=0.01)$. Of the seven patients in the 1988 to 1991 group, four (57\%) were identified with suppurative deep tissue infection after a mean of 7.2 days of appropriate parenteral antibiotic therapy. An additional patient was diagnosed with endocarditis two weeks after completion of a 10 day course of oral penicillin for pharyngitis. Of the remaining two patients, one had bacteremia alone, and the other was an infant with no prior antibiotic therapy who was diagnosed with meningitis upon presentation.

The severity of GAS infection appeared to be greater in the 1988-91 period compared with 1980-88. The mean hospital stay of previously healthy patients as an indicator of illness severity was 17.9 days for 1988-91 and 3.3 days for $1980-88(\mathrm{P}=0.03)$. Complication rates were also higher in the recent group. One patient (case 12) developed avascular necrosis of the femoral head and another (case 15) developed ischemia of the lower extremities requiring bilateral below-knee amputations. An infant with GAS meningitis complicated by subdural effusions (case 17) developed seizures, inappropriate secretion of antidiuretic hormone and pro- 


\section{TABLE 1}

Demographics and clinical characteristics of children with bacteremia caused by group A streptococci, 1980-1991

\begin{tabular}{|c|c|c|c|c|c|c|c|c|c|c|c|}
\hline $\begin{array}{l}\text { Patient } \\
\text { number }\end{array}$ & Year & Age & Sex & $\begin{array}{l}\text { Underlying } \\
\text { illness }\end{array}$ & Rash & $\begin{array}{l}\text { Presentation } \\
\text { Myalgias and } \\
\text { hyperesthesia }\end{array}$ & $\begin{array}{l}\text { Nonweight } \\
\text { bearing }\end{array}$ & $\begin{array}{c}\text { Deep tissue } \\
\text { infection }\end{array}$ & $\begin{array}{l}\text { Manifestation of } \\
\text { deep tissue } \\
\text { infection after start } \\
\text { of therapy (days) }\end{array}$ & Surgical procedure & $\begin{array}{r}\text { Duration of hospital- } \\
\text { ization of previously } \\
\text { normal host (days) }\end{array}$ \\
\hline 1 & 1983 & 9 months & M & - & - & - & $N / A$ & Osteomyelitis & 0 & Incision and drainage & 5 \\
\hline 2 & 1983 & 3 years & $M$ & + & - & - & - & - & & - & $\mathrm{N} / \mathrm{A}$ \\
\hline 3 & 1983 & 8 years & $M$ & - & - & - & - & - & & - & 7 \\
\hline 4 & 1983 & 5 years & $M$ & - & MP & - & - & - & & - & 3 \\
\hline 5 & 1984 & 8 years & $\mathrm{F}$ & + & MP & - & + & - & & - & $N / A$ \\
\hline 6 & 1985 & 7 years & M & - & MP & - & - & - & & - & 5 \\
\hline 7 & 1985 & 4 years & $M$ & - & - & - & - & - & & - & 0 \\
\hline 8 & 1985 & 4 years & $M$ & - & - & - & - & - & & - & 0 \\
\hline 9 & 1986 & 4 months & $M$ & + & Ex & - & - & - & & - & $N / A$ \\
\hline 10 & 1988 & 4 years & $M$ & + & - & - & + & $\begin{array}{l}\text { Septic arthritis, } \\
\text { osteomyelitis }\end{array}$ & 0 & $\begin{array}{l}\text { Arthrocentesis, } \\
\text { debridement }\end{array}$ & N/A \\
\hline 11 & 1989 & 3 years & $\mathrm{F}$ & + & - & - & + & - & & - & 2 \\
\hline 12 & 1989 & 6 years & $M$ & - & EPP & + & + & Septic arthritis & 4 & Arthrocentesis & 22 \\
\hline 13 & 1989 & 11 months & $\mathrm{F}$ & - & EPP & + & $N / A$ & Osteomyelitis & 2 & - & 13 \\
\hline 14 & 1989 & 7 years & $\mathrm{F}$ & - & EPP & + & + & Osteomyelitis & 7 & - & 26 \\
\hline 15 & 1990 & 15 years & $M$ & - & S.EPP & + & + & $\begin{array}{l}\text { Septic arthritis, } \\
\text { osteomyelitis }\end{array}$ & $\begin{array}{l}5 \\
8\end{array}$ & $\begin{array}{l}\text { Arthrocentesis, } \\
\text { debridement, } \\
\text { bilateral below knee } \\
\text { fasciotomies, } \\
\text { bilateral below knee } \\
\text { amputations }\end{array}$ & 30 \\
\hline 16 & 1990 & 7 years & $M$ & - & - & - & - & Endocarditis & 0 & $\begin{array}{l}\text { Open cardiac } \\
\text { massage }\end{array}$ & Died in hospital \\
\hline 17 & 1991 & 5 weeks & $\mathrm{F}$ & - & - & - & - & Meningitis & 0 & $\begin{array}{l}\text { Drainage subdural } \\
\text { effusion }\end{array}$ & 24 \\
\hline 18 & 1991 & 5 years & $M$ & - & MP & - & - & - & & & 8 \\
\hline
\end{tabular}

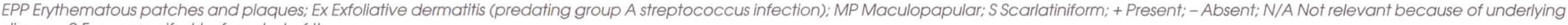
disease; O Focus manifest before start of therapy 
longed irritability. Another patient (case 18) developed septic shock and acute renal tubular necrosis. In contrast, there were no complications or sequelae from GAS infection in the 1980-88 group.

A distinct clinical syndrome consisting of myalgias, hyperesthesia and rash was noted in a subset of four of nine patients in the 1988-91 study period which was not identified in the $1980-88$ group. Muscle pain was severe, diffuse and exacerbated by movement which resulted in striking immobility during the early phase of illness. Generalized hyperesthesia was present in three of the four patients (the fourth patient being an infant in whom this symptom could not be discerned although she was irritable with handling). Exquisite tenderness on skin palpation was described.

Although rash occurred in patients in both groups (five [55\%] in the 1980 to 1987 period and three [33\%] in the 1988 to 1991 period), a distinctive rash consisting of several erythematous, tender patches and plaques over the extremities and trunk was documented in the subset of four patients in the 1988-91 group only. These lesions were evanescent in nature, fading and reappearing over several days. They were distinct from the lesions of erythema nodosum (also described with GAs infection) because they lacked nodularity, were transient in nature and did not progress to a purple discoloration. Details of two cases follow.

Case 12: A previously healthy seven-year-old boy was taken to hospital with $48 \mathrm{~h}$ of fever, sore throat, and lower limb pain which had led to refusal to bear weight for the previous $24 \mathrm{~h}$. He appeared ill and refused to move because of marked generalized muscle pain and hyperesthesia. There were erythematous patches and plaques over his ankles and feet. Peripheral blood leukocyte count was $11 \times 10^{9} / \mathrm{L}$ with $37 \%$ neutrophils and $40 \%$ band forms. A rapid streptococcal antigen test from a pharyngeal swab was positive; GAS were isolated from the blood and pharynx. Penicillin G (250,000 U/kg/day) was given intravenously. His muscle pain resolved over four days except for left thigh and hip pain. A technetium bone scan revealed an avascular femoral head. GAS were isolated from synovial fluid taken from the left hip four days after the start of antimicrobial therapy. A repeat bone scan one week later showed persistent avascularity.

Case 15: A previously healthy 15-year-old male developed a biphasic illness consisting of sore throat and cervical adenopathy which resolved over a week, followed by fever, malaise and myalgias. During the $24 \mathrm{~h}$ before hospitalization, he refused to bear weight, and developed diarrhea, weakness, confusion and a rash on his legs and trunk. At admission, he had mottled skin, cool extremities, oral temperature of $37.4^{\circ} \mathrm{C}$, blood pressure of $100 / 50 \mathrm{mmHg}$ and heart rate of 160 beats/min. He complained of generalized, severe muscle tenderness and hyperesthesia, most marked in his lower extremities. There was exudative tonsillitis with a strawberry tongue, and a generalized scarletiniform rash and erythematous patches on his ankles and feet. The peripheral blood leukocyte count was $19 \times 10^{9} / \mathrm{L}$ with $38 \%$ neutrophils and $60 \%$ band forms. The serum creatinine phosphokinase was $12,000 \mathrm{U} / \mathrm{L}$ (normal range 20 to 200). The rapid streptococcal antigen test on a pharyngeal swab was positive; GAS were isolated from the pharynx and blood.

Cloxacillin (100 mg/kg/day) and cefotaxime (150 $\mathrm{mg} / \mathrm{kg} /$ day) were administered intravenously initially and changed to penicillin G $(250,000 \mathrm{U} / \mathrm{kg})$ when the culture results were available. Although adequate blood pressure was maintained with dopamine (10 $\mathrm{\mu g}$ / $\mathrm{kg} / \mathrm{min}$ ), the patient developed cool, pulseless lower extremities $12 \mathrm{~h}$ after hospitalization. Clindamycin (30 $\mathrm{mg} / \mathrm{kg} /$ day) was added and fasciotomies of the lower extremities and right forearm were performed; although necrotizing fasciitis was not found, GAS were isolated from the sites. Because of loss of tissue viability, bilateral below-knee amputations were required on the 10th hospital day. Further surgical exploration on the 26th hospital day because of right wrist pain and swelling showed resolving infection of the lunate.

Strain typing: $\mathrm{M}$ and $\mathrm{T}$ antigen characterization was done on five of nine GAS isolates from the 1988-91 period. Two were $\mathrm{M}$ and $\mathrm{T}$ type 12 , two were $\mathrm{M}$ and $\mathrm{T}$ type 1 , and one was $M$ type nondeterminant and $T$ type 12. All nine isolates from this period had mucoid colony morphology.

\section{DISCUSSION}

Since 1987, several reports have described an increased severity of GAS infections without an apparent increased incidence $(24,25)$. In the present study, we also did not find an increased frequency of detection of bacteremia caused by GAS; however, the frequency of severe infection as reflected by associated deep tissue invasions and length of hospital stay significantly increased in recent years. Other investigators have reported both increased incidence and severity of GAS infections $(8-14,19,20)$. Whereas infections caused by invasive GAS were associated with the immunocompromised host $(26,27)$, this study and others $(14,19$ $21,24,28$ ) have demonstrated that severe GAS infection more commonly occurs in the previously healthy individual.

Two patterns of disease were apparent in the 198891 group of children: bacteremia alone with an uncomplicated clinical course; and bacteremia with deep tissue infection and more serious clinical course. In the group of children with bacteremia and deep tissue infection, a subset of children in the 1988-91 group presented with a symptom complex which included a distinctive rash of erythematous patches and plaques, intense myalgias, hyperesthesia and refusal to bear weight on the lower extremities. This combination of symptoms upon initial presentation of GAS disease 
seen in our patients has not been described in the literature, although isolated symptoms have. The intense pain in either muscle or skin was the initial presentation in five of seven patients old enough to describe their symptoms, and marked irritability was noted in the remaining two infants. Similarly, intense skin pain was the most common initial symptom in the adult patients described by Stevens et al (17). Jackson et al (22) also noted pain and hyperesthesia in their series of children.

Three of four patients in the 1988-91 group who presented with this symptom complex had deep tissue infections that were identified after several days of antibiotics, despite the GAS being uniformly sensitive to penicillin in all these cases. Patient 15 had osteomyelitis of the capitate identified 23 days after initiation of intravenous penicillin, tibial osteomyelitis was diagnosed nine days after treatment was started in patient 14 , and patient 12 had septic arthritis of the hip identified after four days of intravenous penicillin. Despite daily physical examinations, clinical identification of deep tissue invasions was delayed in these patients. This delay may have been due to the difficulty in identifying localizing signs in the face of generalized myalgias or may reflect the severity of the GAS infection.

Several hypotheses have been proposed for the resurgence of GAS severe disease. A shift in serotypes of GAS has been documented with an increased frequency of isolation of M-1, M-3 and M-18 types of GAS in both rheumatic fever outbreaks, bacteremia and severe disease, and toxic shock-like syndrome $(8,14,17,28-30)$. These serotypes, although common in the preantibiotic era, were recovered infrequently up to the last five years. Most of the GAS isolates from patients with toxic shock-like syndrome in North America produced streptococcal pyrogenic toxin A $(17,31)$. This toxin was commonly found in the preantibiotic era; however, in recent years, streptococcal pyrogenic toxin B or a combination of toxins $\mathrm{B}$ and $\mathrm{C}$ has been predominant in GAS isolates.

\section{REFERENCES}

1. Veasy LG, Wiedmeier SE, Orsmond GS, et al. Resurgence of acute rheumatic fever in the intermountain area of the United States. N Engl J Med 1987;316:421-7.

2. Hosier DM, Craenen JM, Teske DW, Wheller JJ. Resurgence of acute rheumatic fever. Am J Dis Child 1987; 141:730-3.

3. Congeni B, Rizzo C, Congeni J, Sreenivasan VV. Outbreak of acute rheumatic fever in northeast Ohio. J Pediatr 1987;111:176-9.

4. Wald ER, Dashefsky B, Feidt C, Chiponis D, Byers C. Acute rheumatic fever in western Pennsylvania and the tristate area. Pediatrics 1987;80:371-4.

5. Griffiths PS, Gersony WM. Acute rheumatic fever in New York City (1969-1988): A comparative study of two decades. J Pediatr 1990;1 16:882-7.

6. Westlake RM, Graham TP, Edwards KM. An outbreak of acute rheumatic fever in Tennessee. Pediatr Infect Dis J 1990;9:97-100.

7. Sampson GL, Williams RG, Wetzel NE, et al. Acute
Unfortunately, of the isolates in the present series, toxin production was not sought and M-typing was done on a sample of the isolates from the 1988-91 period only. Therefore, we cannot comment on any change of M-type or toxin production of isolates from the two study groups. Mucoid colony morphology, indicating an abundant hyaluronic acid capsule, has also been associated with increased GAS virulence. The predominance of mucoid strains in recent years may also have contributed to the increased severity of GAS disease.

Host factors also are likely to contribute to the increased severity of GAS disease. Antibody to the M protein confers serotype immunity on the host; the rarity of these serotypes in recent years has resulted in a highly susceptible population. This situation is further exacerbated by a coincident shift to a more frequent isolation of GAS producing pyrogenic toxin A resulting in a susceptible population lacking protective antibody to the toxin. Some have proposed that both deep tissue infection and toxic shock-like illness are different manifestations of infection depending on the immune status of the host. Thus, severe disease may occur in individuals lacking serotype (M-type) antibody whereas invasive infection with toxic shock-like syndrome may occur in individuals lacking both serotype and toxin antibody $(32,33)$.

Management of patients with GAS infection must include vigilance for ongoing suppurative complications. The progression of infection and development or recognition of deep tissue infection during appropriate antimicrobial therapy was notable in our patients and was occasionally observed by others (22).

Careful repetitive physical examination and use of radionucleotide imaging are important for identifying and appropriately treating complications. This report emphasizes the need to include GAS in the differential diagnosis of severe infection and to recognize its significant morbidity and mortality even with appropriate antimicrobial therapy.

rheumatic fever among army trainees - Fort Leonard Wood, Missouri, 1987-1988. MMWR 1988;37:519-22.

8. Farley JD, Woo V, Shaw C, Smith JA. Invasive streptococcal disease in British Columbia. Can Dis Wkly Rep 1991;16:257-9.

9. Demers B, Simor AE, Vellend H, Low DE. Severe group A streptococcal disease - Toronto, Ontario. Can Dis Wkly Rep 1991;16:259-60.

10. Voeck C, Armstrong N, Trail F, et al. Group A beta-hemolytic streptococcal bacteremia - Colorado. MMWR 1990;39:3-4.

11. Braunstein H. Characteristics of Group A streptococcal bacteremia in patients at the San Bernardino County Medical Center. Rev Infect Dis 1991;13:8-11.

12. Strömberg A, Romanus V, Burman LG. Outbreak of Group A streptococcal bacteremia in Sweden: An epidemiologic and clinical study. J Infect Dis 1991;164:595-8.

13. Ispahani P, Donald FE, Aveline AJD. Streptococcus pyogenes bacteraemia: An old enemy subdued, but not 
defeated. J Infect 1988;16:37-46.

14. Martin PR, Hoiby EA. Streptococcal serogroup A epidemic in Norway 1987-1988. Scand J Infect Dis 1990;22:421-9.

15. Cone LA, Woodward DR, Schlievert PM, Tomory GS. Clinical and bacteriologic observations of a toxic shock-like syndrome due to Streptococcus pyogenes. N Engl J Med 1987;317:146-9.

16. Bartter T, Dascal A, Carroll K, Curley FJ. 'Toxic strep syndrome': A manifestation of Group A streptococcal infection. Arch Intern Med 1988;148:1421-4.

17. Stevens DL, Tanner MH, Winship J, et al. Severe group A streptococcal infections associated with a toxic shock-like syndrome and scarlet fever toxin A. N Engl J Med 1989;321:1-7.

18. Christie CDC, Havens PL, Shapiro ED. Bacteremia with Group A streptococci in childhood. Am J Dis Child 1988;142:559-61.

19. Wheeler MC, Roe MH, Kaplan EL, Schlievert PM, Todd JK. Outbreak of Group A streptococcus septicemia in children: Clinical, epidemiologic, and microbiological correlates. JAMA 1991;266:533-7.

20. Givner LB, Abramson JS, Wasilauskas B. Apparent increase in the incidence of invasive group $A$ beta-hemolytic streptococcal disease in children. J Pediatr 1991;118:341-5.

21. Harnden A. Serious suppurative infections in previously well children. Pediatr Infect Dis J 1988;7:714-8.

22. Jackson MA, Burry VF, Olson LC. Multisystem Group A $\beta$-hemolytic streptococcal disease in children. Rev Infect Dis 1991;13:783-8.

23. Facklam RR, Washington JA II. Streptococcus and related catalase-negative Gram-positive cocci. In: Balows A, Hausler WJ Jr, Herrmann KL, Isenberg HD, Shadomy HJ, eds. Manual of Clinical Microbiology, 5th edn.
Washington: American Society for Microbiology, 1991:238-57.

24. Wong VK, Wright HT. Group A beta-hemolytic streptococci as a cause of bacteremia in children. Am J Dis Child 1988;142:831-3.

25. Begovac J, Marton E, Lisic M, et al. Group A beta-hemolytic streptococcal toxic shock-like syndrome. Pediatr Infect Dis J 1990;9:369-70.

26. Yagupsky P, Giladi Y. Group A beta-hemolytic streptococcal bacteremia in children. Pediatr Inf Dis J 1987;6:1036-9.

27. Dudding B, Humphrey GB, Nesbit ME. Beta-hemolytic streptococcal septicemias in childhood leukemia. Pediatrics 1969;43:359-64.

28. Schwartz B, Facklam RR, Breiman RF. Changing epidemiology of group A streptococcal infection in the USA. Lancet 1990;336:1167-71.

29. Gaworzewska ET, Colman G. Changes in the pattern of infection caused by Streptococcus pyogenes. Epidemiol Infect 1988;100:257-69.

30. Kaplan EL, Johnson DR, Cleary PP. Group A streptococcal serotypes isolated from patients and sibling contacts during the resurgence of rheumatic fever in the United States in the mid-1980s. J Infect Dis 1989;159:101-3.

31. Belani K, Schlievert PM, Kaplan EL, Ferrieri P. Association of exotoxin-producing Group A streptococci and severe disease in children. Pediatr Infect Dis J 1991;10:351-4.

32. Ferrieri P. Microbiological features of current virulent strains of Group A streptococci. Pediatr Infect Dis J 1991;10:S20-4.

33. Stevens DL. Invasive Group A streptococcus infections. Clin Infect Dis 1992;14:2-13. 


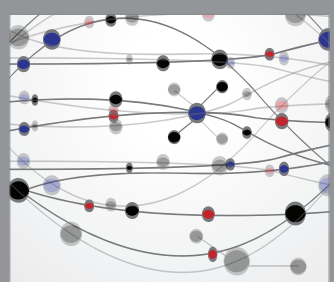

The Scientific World Journal
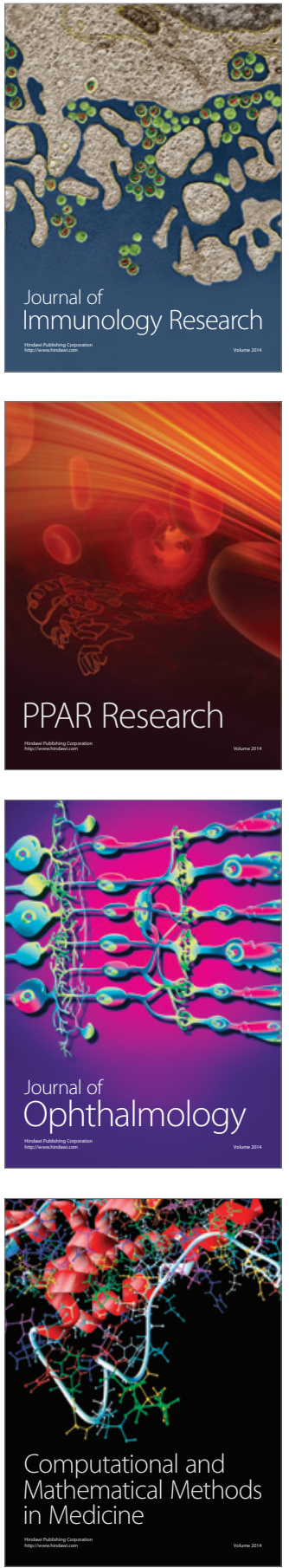

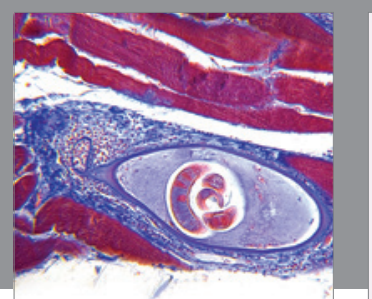

Gastroenterology Research and Practice

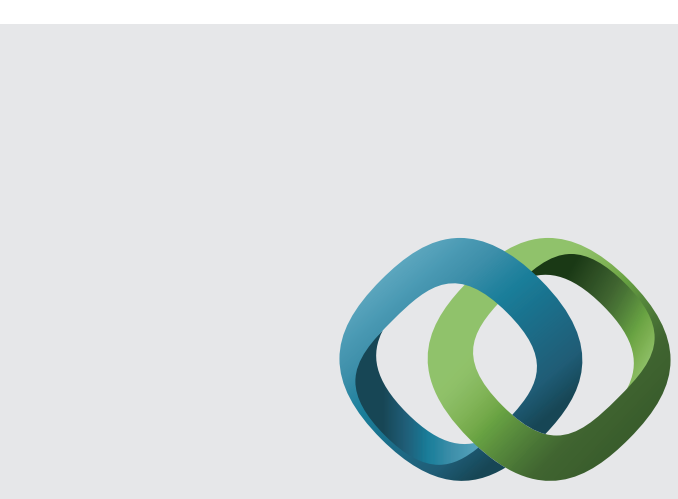

\section{Hindawi}

Submit your manuscripts at

http://www.hindawi.com
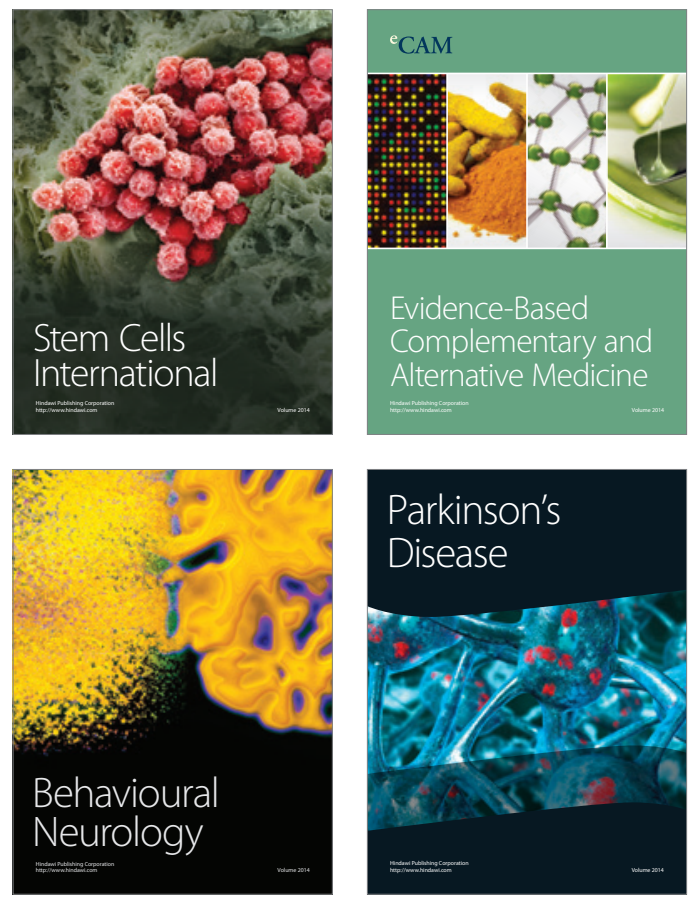
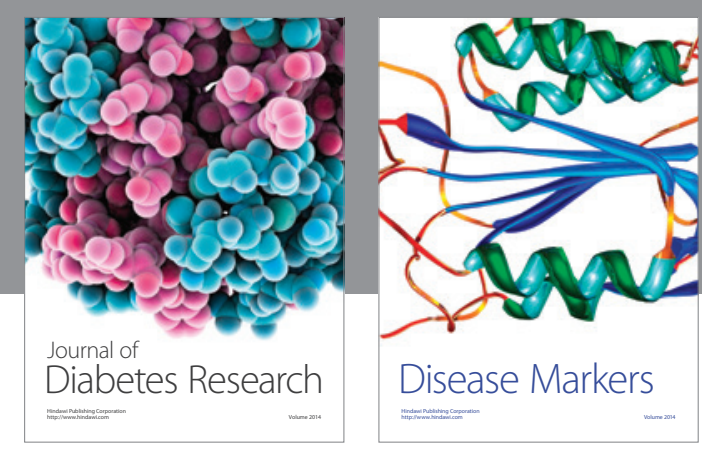

Disease Markers
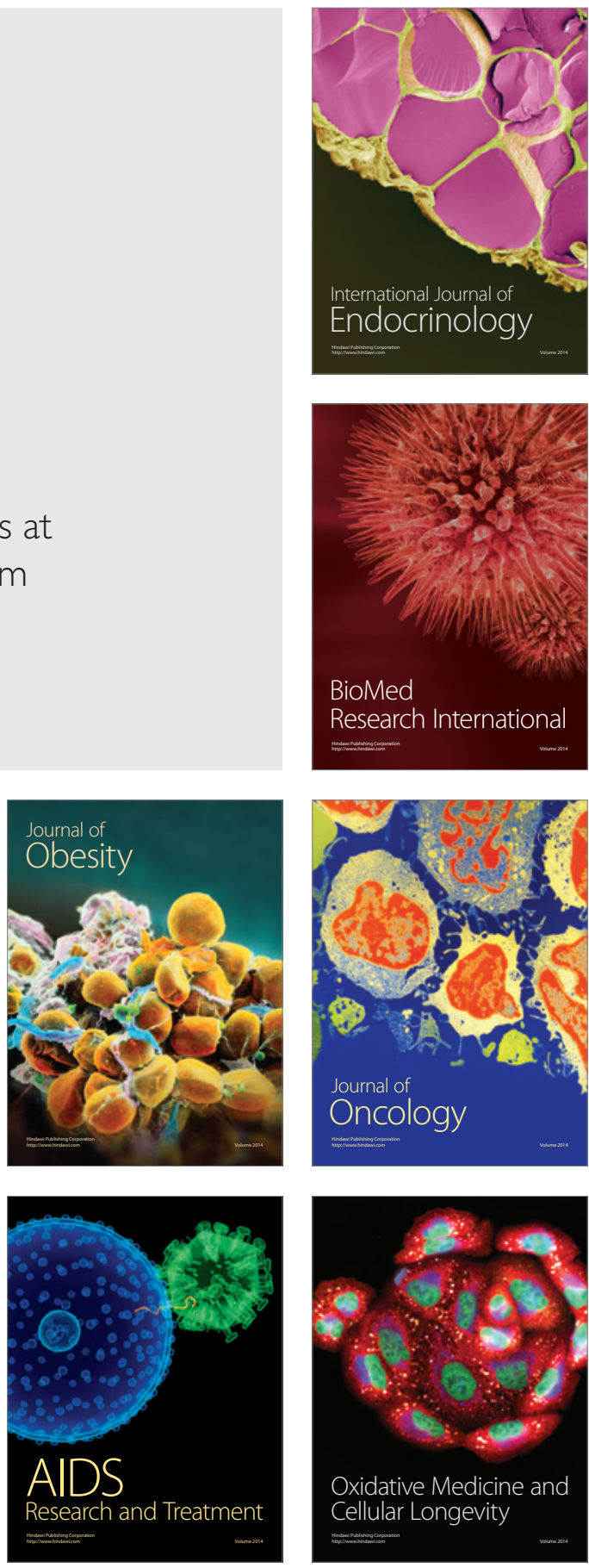